Article

\title{
Dependence of Total Production Costs on Production and Infrastructure Parameters in the Polish Hard Coal Mining Industry
}

\author{
Izabela Jonek-Kowalska * and Marian Turek
}

Faculty of Organization and Management, Silesian University of Technology, Roosevelt 26 Street, 41-800 Zabrze, Poland; marian.czeslaw.turek@polsl.pl

* Correspondence: izabela.jonek-kowalska@polsl.pl; Tel.: +48-32-2777336

Academic Editor: Henrik Lund

Received: 3 September 2017; Accepted: 21 September 2017; Published: 25 September 2017

\begin{abstract}
European hard coalmining is a declining industry, despite the use of hard coal for energy in several countries. Industry restructuring and public subsidies have failed to stop this industry's decline. The largest hard coalmining sector, the Polish sector, has faced an obstacle to its survival: How to reduce production costs to compete with less expensive imported hard coal? This article aims to identify and analyze the dependence of the total production costs representing production and infrastructure parameters of the Polish hard coalmining industry. The parameters are divided into three groups: (1) the cost of employees and the production volume; (2) the number of longwalls, the length of a longwall, the daily longwall advance and the preparatory work advance; and (3) the number of levels in exploitation, the number of layers in exploitation and the number of shafts. The findings indicate that, even in well-functioning coalmines, there are many economically irrational relationships, especially regarding employment and infrastructure size. This study shows that employment, which is a significant cost component of the production and infrastructure parameters of the examined Polish hard coalmines, is not economically rational in terms of its proportion to the total production costs. As a result, even a considerable reduction in employment or infrastructure does not influence the unit costs of mining production, which could only be partially explained by the high level of fixed costs. There are also no appropriate relationships between infrastructure parameters and the total production cost. Under these irrational conditions, a reduction in the production costs of hard coalmining enterprises is difficult, but unproductive costly activities could prevent an improvement in production efficiency. Only restoring the proper relationship between economic and infrastructure parameters and the total production costs can ensure a return to price competitiveness. Those actions are crucial for the Polish hard coalmining industry, because the research focused on successful hard coalmines that were not declining indicate it should be able to implement cost improvements.
\end{abstract}

Keywords: total production costs; coal production parameters; coal-mines infrastructure parameters; coalmining

\section{Introduction}

\subsection{Financial Specificity of Hard Coal Mining}

Underground coalmining is a sector with a complex production process, requiring interdisciplinary knowledge and competencies, including, geology, tectonics, geodesy, civil engineering, mining, mechanics, chemistry and environmental protection. Additionally, each mining lifecycle stage requires large capital expenditures, including the liquidation stage, due to the reclamation processes 
and the requirement to repair the damage caused by coalmines. Therefore, hard coalmining is a capital-intensive industry [1].

The aforementioned conditions significantly affect the efficiency of hard coalmining production and require efficient cost management, especially regarding long-term cost predictions [2,3]. To be profitable, management knowledge and experience working in the hard coalmining sector is crucial because production costs depend not only on current expenditures but also on irreversible and cost-intensive decisions concerning investments in hard coalmine infrastructure. The long-term cost-management perspective is challenging to develop and difficult to implement because of challenges such as the incomplete measurement of the parameters of deposits, a changing economic environment, and the long-term market forecast. Moreover, there are several subjective challenges related to political and social conditions, as well as the prioritization of production goals, such as the maximization of hard coal extraction, national energy safety, the maintenance of employment levels and the prevention of the economic collapse of the region [4]. In several cases, especially in less developed economies, the long-term cost planning of the hard coalmining sector is replaced by a policy of reducing current costs, resulting in the destruction of local societies, economies and the environment. As a result, the cost-intensiveness of hard coalmining causes ethical, social and environmental abuse and results in activities that harm the public image of the hard coalmining sector.

The circumstances mentioned above justify the necessity of conducting research on the area of costs in coalmining in the general perspective, but, in each geographic localization, there are also specific reasons that motivate considering financial aspects of extractive industries. Therefore, the next part of the article concerns Polish coalmining. Such approach enables deeper analysis and it includes following issues:

- The description of the previous and current situation in Polish coalmining industry;

- The review of literature on costs in Polish coalmining;

- The case studies analysis including examining the relationships between main production and infrastructure parameters and production costs;

- The indication of irregularities in examined relationships and the ways of removing them that are oriented at improving efficiency in Polish coalmining.

\subsection{Insights from Coal Mining in Poland}

This study concerns the cost management of Polish hard coalmining enterprises by examining the dependence of total production costs on the costs of production and infrastructure parameters. The context of the study is coalmining in Poland, which is one of the largest producers of hard coal globally. However, the Polish hard coalmining sector is struggling, primarily due to the decarbonization of the European Union, decreasing hard coal consumption by the local and regional markets and the decreasing price competitiveness of the sector. The latter is caused by the continued increase in unit costs, which justifies research on the cost determinants of the Polish hard coalmining industry and makes the results of the study applicable to the industry. Since 1990, sales of hard coal in Poland have dropped by $56 \%$ while the unit cost of production has increased more than fifteen times. The main causes of the unit cost increase are: the high share of fixed costs, including remuneration costs, in the total production costs and deterioration of mining condition (deepening of excavation and increase in natural hazards). As the result of the long-term crisis, the number of coalmines in Poland has decreased from 70 to 14 . Nevertheless, hard coal remains the most important energy source with the share in total energy consumption being $55 \%$, thus, for this reason, the improvement of its price competitiveness is crucial for the survival of the industry.

The decreased price competitiveness of Polish hard coal resulted in decreased domestic sales and reduced exports (Figure 1). These effects were especially pronounced over the last three years because of the global decrease in hard coal prices, which further decreased production efficiency through 
increased unit costs. As a result, since 2008, Poland, the primary energy resource of which is hard coal, has imported more hard coal than it has exported (Figure 1).

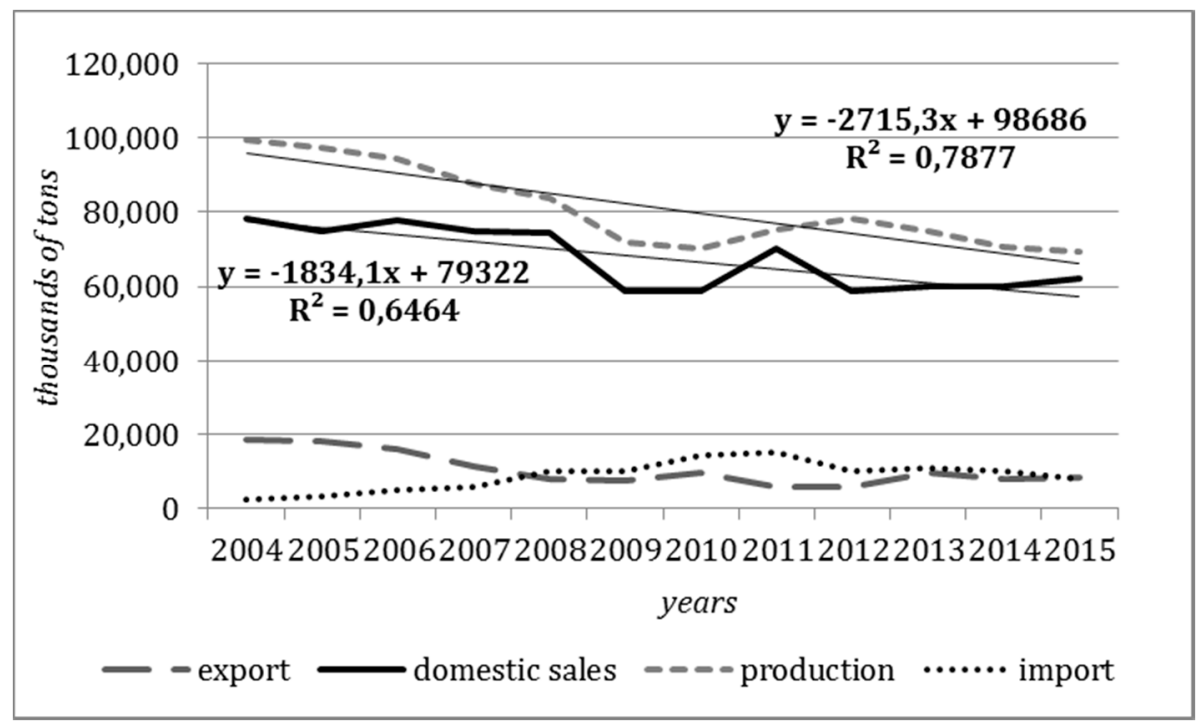

Figure 1. Production, domestic sales, imports and exports of hard coal in Poland over the period of 2004 to 2015 (in thousands of tons). Source: own work.

Since the European Commission abolished state operating subsidies in 2010, the Polish hard coalmining industry has dramatically declined. By 2015, the loss of operating subsidies forced the hard coalmining sector to restructure, resulting in consolidation of economically efficient hard coalmining enterprises and liquidation of economically inefficient hard coalmining enterprises. The hard coalmining enterprises that survived the restructuring and are currently operating must take steps to reduce their unit costs and increase their price competitiveness to avoid liquidation and ensure the energy security of Poland.

\subsection{Literature Studies on Costs in Coal Mining in the Context of Research Intends}

The previous literature rarely addresses mining production costs, primarily due to the technical and interdisciplinary nature of the industry. The extant studies focus on using new technologies for coalmining and improving employee safety in coalmines [5-11]. Therefore, coalmining production costs are scarcely researched.

Issues of health and wellness include not only protection from natural hazards during coalmining [12] but also the safety of local and regional citizens that are exposed to the harmful by-products of coalmining production [13,14]. All actions taken by coalmining enterprises to improve the health and wellness of employees and citizens require additional expenditures that increase mining production costs. However, the previous literature and research shows that these costs could be efficiently optimized [15-17].

A primary interest of coalmining enterprises is implementing clean coal technologies (CCT). Therefore, the calculation and reduction of the cost of implementing CCT is the focus of existing research [18-20]. The most promising of the new CCTs is the Natural Gas Combined Cycle (NGCC). This cycle significantly reduces $\mathrm{CO}_{2}$ emissions through a highly efficient use of energy. The increased efficiency of power generation in an integrated system of steam and gas with coal gasification (IGCC -Integrated Gasification Combined Cycle) reduces carbon dioxide emissions. Moreover, the benefit of IGCCs over combustion systems is a result of a more efficient removal of carbon dioxide from emissions [21]. Many previous studies on coalmining have examined greenhouse gas (GHG) emissions and underground carbon dioxide storage [22]. 
Because of the development of and increasing interest in sustainable development (SD), the number of publications devoted to the environmental and social aspects of mining has increased [23-30]. Research on the SD of the mining industry focuses on reclamation costs [31-35], the balance of expenditures, the level of local communities' satisfaction with the mining enterprise and the public image of the mining enterprises [36,37]. Furthermore, the social costs of mining are analyzed [38-40]. Additionally, researchers evaluate the effect of by-product use on mining production efficiency [41-44]. The study of the environmental and social effects of coalmining allows researchers to evaluate the product life cycle (PLC) of coal [45]. Moreover, several studies have focused on the procedures and the costs of the disposal of mining waste using methods that protect the environment $[46,47]$.

Another area of cost analysis research includes the cooperation of mining enterprises. Mining enterprises may participate in vertical relationships, in which the mining enterprises cooperate with the energy industry, or in horizontal relationships, in which mining enterprises consolidate [48-50]. The primary aim of those relationships is to achieve synergy between mining production and investment [51].

Based on the aforementioned studies, one could conclude that the extant literature on mining is focused on the advanced and specialized elements of cost management. However, all cost management elements require stable and sufficient financing. Such financing could be assured if a mining enterprise operates efficiently and produces positive financial results, which earns the enterprise financial credibility [52-55]. In the mining industry, work safety, environmental protection, implementing new technologies and sustainable development are not possible without adequate financial support [56-58]. Therefore, research on the operational cost management of mining enterprises is still uncommon, and more studies are warranted. The extant research addresses three aspects of the operational cost management of mining enterprises. The first aspect addresses the unit cost calculations and their determinants [59]. The second aspect relates to the costs of new operational investments, such as new longwalls. The third aspect focuses on strategic investments, such as building a mine or opening a mining deposit [60-62].

Due to the capital intensity of mining production, a considerable number of studies focus on investigating the proportion of fixed to variable costs. In this study, the linear function of the total production costs is used to estimate and predict the unit costs in selected Polish hard coalmines based on data regarding production volume and the historic total production costs. The results show that, in the Polish hard coalmining sector, fixed costs make up a higher proportion of total production costs than in other industries. This is because of the need to maintain a large mining infrastructure and to guarantee environmental safety, even during periods of reduced or paused production. In the Polish hard coalmining sector, the proportion of fixed costs has been rising because of the high wages demanded by the trade unions. Several cost models have been developed based on the structure of fixed costs, including amortization, materials, energy, wages, and services. Additionally, these costs are linear functions. However, the coefficients are independent variables defined as the share of each cost in the total production cost structure.

The majority of the aforementioned research is on the enterprises' internal perspective of cost estimations and predictions and does not address mining production. They focus on mining production cost regularities. This study addresses this knowledge gap through research on project-based costing in which the direct costs of hard coalmining enterprises are budgeted from zero for each new longwall and the indirect costs are calculated using the appropriate accounting indicators. This approach enables the research to take into account the exact capital expenditures and varied geological conditions of hard coalmining enterprises as well as the level of natural hazards characterizing each newly opened longwall. However, the method is time-consuming and complicated because a considerable share of the total production costs of hard coalmining enterprises is indirect costs.

Because of the aforementioned financial and technical complications, the research on mining production costs frequently focuses on a single source of production costs. Importantly, the quality 
and size of each tangible and intangible cost as well as human resource costs are crucial determinants of total mining production costs and must be included in the cost analyses. Therefore, in this article, the authors evaluate the relationship between production and infrastructure parameters and their influence on the total production costs of hard coalmining enterprises [63-65]. This study furthers previous research on the Polish hard coalmining sector by the Central Mining Institute over the period of 2006 to 2009. It evaluated the feasibility of examining and forecasting the unit production costs of hard coalmining enterprises when taking into account the technical and organizational parameters of hard coalmines. The study used linear regression models and included an analysis to determine the amount of the total production costs that depended on technical and production parameters. However, the study did not directly analyze the economic rationality of the examined correlations or their effect on the financial performance of the hard coalmines and the hard coalmining industry of Poland.

Based on the aforementioned justification and conditions of the Polish hard coalmining sector, we pose the following research questions: (1) How does the reduction in employment and production influence the total production costs of Polish hard coalmining enterprises? (2) How do the changes to the infrastructure of Polish hard coalmining enterprises affect their production costs? In the Section 2, these research questions are the basis of four research hypotheses that are tested using Pearson's coefficients and linear regression models.

This paper addresses the research questions in the following order. In Section 2, the research method is described. In Section 3, three categories of cost determinants are described, and their influence on the total production costs of five hard coalmines is estimated. In the summary, the implications for the policies concerning the Polish hard coalmining sector are discussed and future research topics are suggested.

\section{Methods and Materials}

As stated in the Introduction, hard coalmining is a capital-intensive industry that has a long payback period. Therefore, the current financial position and investment decisions of hard coalmining enterprises have an irreversible effect on their financial performance. There are three categories of coalmining production cost determinants [66]. The first category includes the costs of production parameters, such as employment and production volume. This category is broadly addressed in the current literature in the context of unit costs structure and fixed and variable costs [67-71]. The second category includes the costs of technical parameters that indicate current excavation conditions, such as the number of longwalls, the length of a longwall, the daily longwall advance and the preparatory work advance. These determinants describe present operational conditions and change dynamically based on production capacity and plans. The third category includes the costs of technical parameters of the hard coalmine model that are constant over the long-term and meet production requirements, such as the number of levels in exploitation, the number of layers in exploitation and the number of shafts.

As the costs of the parameters of the first and the third group increase, the total production costs should increase and the costs of the parameters should be positively correlated with the total production costs because they contribute to the production and infrastructure development of a hard coalmining enterprise [72,73]. By contrast, as the cost of these parameters decrease, total production costs should decrease. Additionally, the costs of the concentration of excavation-indicated by a reduction in longwalls and the increased length of a longwall-could be associated with a decrease in total production costs. These relationships result from economic regularities and allow us to formulate the following research hypothesis:

Hypothesis 1 (H1). A reduction in employment (A) and production (B) causes a decrease in total production costs. 
Hypothesis 2 (H2). The concentration of mining production (indicated by a reduction in longwalls and the increased length of a longwall) reduces total production costs.

Hypothesis 3 (H3). Reducing the number of levels (A), layers (B), and shafts (C) reduces total production costs.

The third category of parameters, including the average daily longwall advance and the average preparatory work advance, directly affect hard coalmining productivity and require additional inputs that increase the total production cost but decrease the unit production cost. These economic assumptions allow us to formulate the fourth research hypothesis:

Hypothesis 4 (H4). An increase in the dynamic infrastructure parameters that improve hard coalmine productivity (average daily longwall advance and average preparatory work advance) increases total production costs.

As discussed, several studies on cost dependencies in extractive industries have analyzed the linear dependence of the total production costs on production volume or other parameters. We verified the presence of linear dependencies between the total production costs and the select parameters. Then, we used the method of analyzing linear dependencies that previous studies employed to ensure that our research findings were comparable to previous findings. Our contribution the literature is as follows: (1) the results of the research; (2) the selection of unstudied independent variables; (3) the assessment of the economic rationality of existing correlations; and (4) the proposal of methods to correct irrational regularities to improve production efficiency.

The research was completed in three stages. During the first stage, the raw data were analyzed in the form of individual parameters for each of the selected hard coalmines. The independent variables were divided into two groups: production and infrastructure. The production group included the employment and production volume, which were the primary factors influencing the total production costs of traditional mining industries. The second group included parameters the define the infrastructure range and its cost-consumption, such as average number of longwalls, number of levels in exploitation, number of layers in exploitation, number of shafts, average longwall length, average daily longwall advance and average preparatory work advance.

In the second stage, the relationship between the total production costs and the selected parameters were examined. First, spread charts were created to assess the shape and type of relationship. Then, to identify linear relationships, the Pearson's coefficient was used to estimate the direction and strength of the graphically observed relationships.

$$
r_{x y}=\frac{\operatorname{cov}(x, y)}{s(x) \times s(y)}
$$

where

$\operatorname{cov}(x, y)$ —ovariance between variables $x$ and $y$;

$s(x)$-standard deviation of the variable $x$;

$s(y)$-standard deviation of the variable $y$.

The Pearson's coefficient takes values from -1 to 1 , and the closer the value is to 1 or -1 , the stronger the correlation is. The significance level $(p)$ was 0.05 , which means that there was a $5 \%$ chance that the finding of a particular correlation was due to random error in the sample (chance).

In the third stage, we further examined the relationships between the total production costs and the selected variables using multiple linear regression analyses, which enabled the determination of the relationships between the independent variables and the dependent variable:

$$
y_{t}=\alpha_{0}+\alpha_{1} x_{1 t}+\alpha_{2} x_{2 t}+\ldots+\alpha_{m} x_{m t}+\xi_{t}
$$

where 
$\alpha_{0} \ldots \alpha_{m}$-parameters of the model;

$x_{1} \ldots x_{m t}$-independent variable; and

$y_{t}$-dependent variable.

We estimated the parameters using the classical least squares method while taking into account the following assumptions: (1) the model is linear; (2) the expected value of the random component is zero and its variance does not change over time; (3) there is no randomization of the random component over time; (4) the explanatory variables are not random variables; and (5) the explanatory variables are independent.

Additionally, we developed two variants of model for each of the examined hard coalmines. The first variant included all selected parameters. The second variant included parameters that were strongly correlated with the total production costs (they had large Pearson's coefficients) and were not strongly correlated among themselves (they did not have large Pearson's coefficients). This approach improves model adjusting and exposes the most important determinants of production costs. It is a result of searching the equations that describe the dependent variable in the best possible way and such methodology is advised in the literature to increase the regression model's credibility. The limited model is created step-by-step by testing the model adjustment and choosing the best one. Using and presenting two models (full and limited one) also enables the comparison between the independent variables influences on production costs.

To assess the fit of the adjusted model to the data, we used the following parameters:

1. R: multiply by the Pearson's correlation coefficient, which measures the strength of the linear association of the independent variables to the dependent variable $(R \in<0 ; 1>)$;

2. $R^{2}$ : multiply by the coefficient of determination, which measures the fit of the model and the proportion of the variability of the dependent variable that is explained by the model $\left(R^{2} \in<0 ; 1>\right.$; 0 -means a lack of fitting and 1 means perfect fitting);

3. $\mathrm{R}^{2}$ adjusted: multiply by the adjusted coefficient of determination, which defines the fit of the model independent from the number of variables and the size of the sample $\left(R^{2} \in<0 ; 1>; 0\right.$-means a lack of fitting and 1 means perfect fitting);

4. $p$ : indicates if the results are statistically significant $\alpha=0.05$ (if $p>\alpha$ then reject H0; if $p<\alpha$ then fail to reject $\mathrm{H} 0 ; \mathrm{H} 0: \beta \mathrm{i}=0$ and $\mathrm{H} 1: \beta \mathrm{i} \neq 0)$; and

5. SE: standard error of the estimate assesses the difference between the value of the dependent variable and the value of dependent variable estimated by the model (the closer that the value of $\mathrm{SE}$ is to zero, the better is the fit of the model).

All parameters are presented in the tables that show the results of the multiple linear regression models for the examined coalmines.

The research was conducted in the Polish hard coalmining sector under the conditions of the restructuring process over the period of 1998 to 2015. At the beginning of the period there were approximately 70 hard coalmines operating in the Upper Silesian region. In 2015, there were 13 remaining and the government divided them into two groups: (1) those with strong financial performance that continued operating; and (2) those with weak financial performance that were liquidated. The five examined hard coalmines belonged to the first group. However, although expected to succeed, their recent production efficiency and competitive cost advantage was unsatisfactory and they required improvements to their cost management to survive and guarantee the energy security of the Polish economy. The importance of the five hard coalmines to Poland justifies their inclusion in the research sample. Thus, we use the case study as a research method. 


\section{Results}

\subsection{Production Costs in the Polish Hard Coal Mining Industry}

As discussed, the reduction of the costs of the Polish hard coalmining industry is crucial for its survival, which protects one hundred thousand jobs and ensures Poland's energy security. If costs do not decrease, then the demand for hard coal will be met by imported hard coal and Poland will be dependent on foreign sources of hard coal.

Across the examined coalmines, total production costs have been consistently rising (Figure 2). There were several reasons for this increase. One reason was the increased depth of excavation and resulting increase in natural hazards. However, several reasons for the increase in total production costs were not economically rational and were caused by the pressure of trade unions to increase employee salaries. These subjective and societally based actions were not intended to improve financial performance and represent fifty percent of remuneration costs in total production costs, causing the economically irrational total production costs to increase over the period studied.

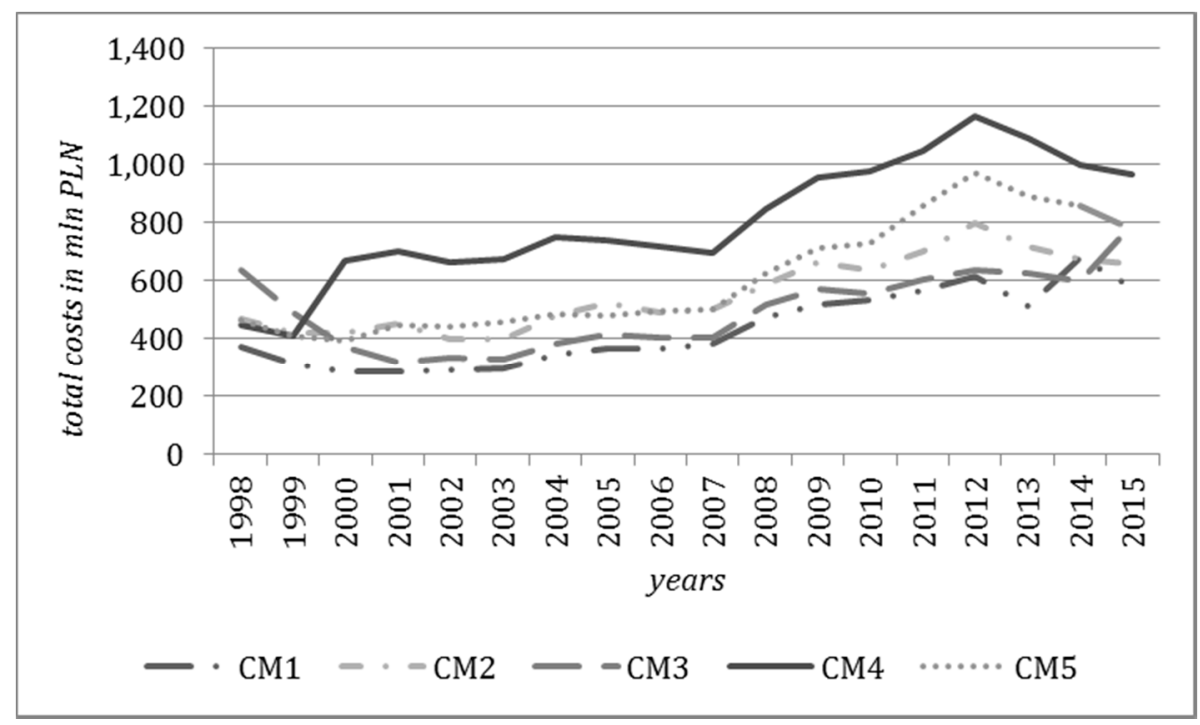

Figure 2. Total production costs of examined coalmines in constant prices of 1998 (mln PLN-Polish New Zloty, the national currency of Poland). Source: own work.

Additionally, the production of Polish hard coalmines has been consistently decreasing in conjunction with declining domestic and European demand. Furthermore, the price competitiveness of Polish hard coal has been decreasing (Figure 3) [74]. The increase in total production costs and fluctuations in hard coal prices caused the sales reduction and the production decrease from $19.5 \mathrm{mln}$ tons to $15 \mathrm{mln}$ tons.

The increase in total production costs and decline in production negatively affected unit costs, which were rising until 2013, as shown in Figure 4. Since 2013, the examined hard coalmines have attempted to reduce unit costs because Polish hard coalmining became at risk for bankruptcy. Their efforts were only partially successful and the restructuring processes must intensify and accelerate to ensure the survival of Polish hard coalmining enterprises. 


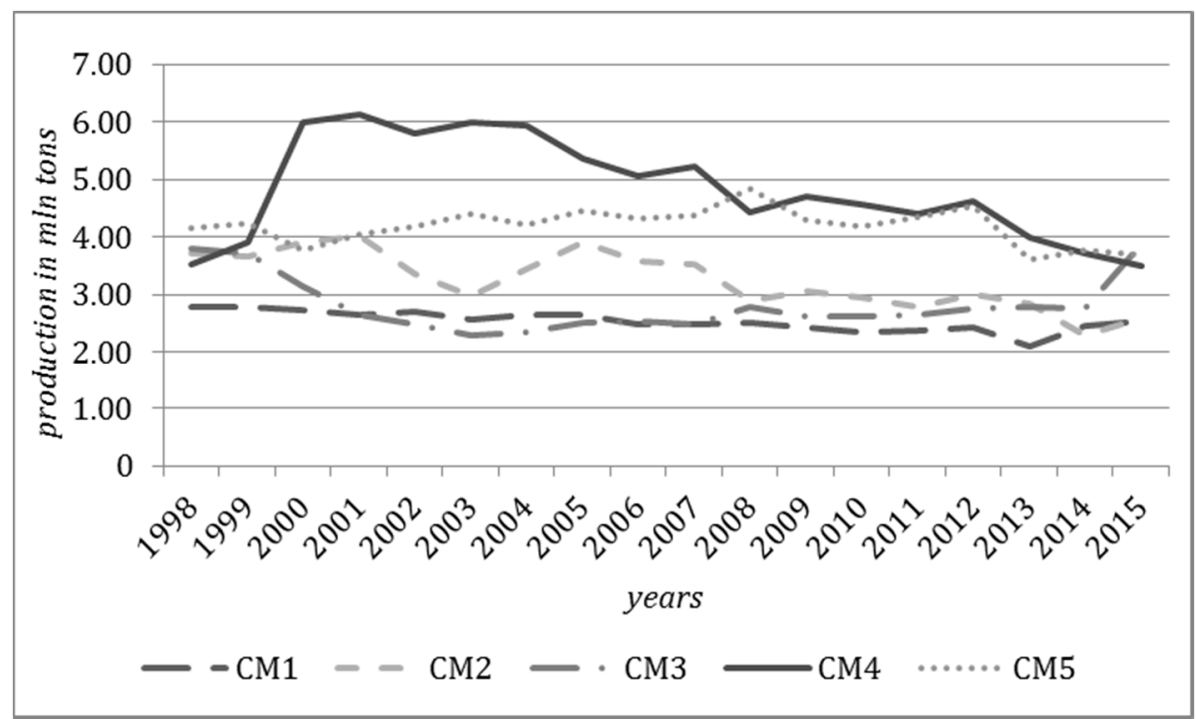

Figure 3. Production of the examined coalmines over the period 1998-2015 ( $\mathrm{mln}$ tons). Source: own work.

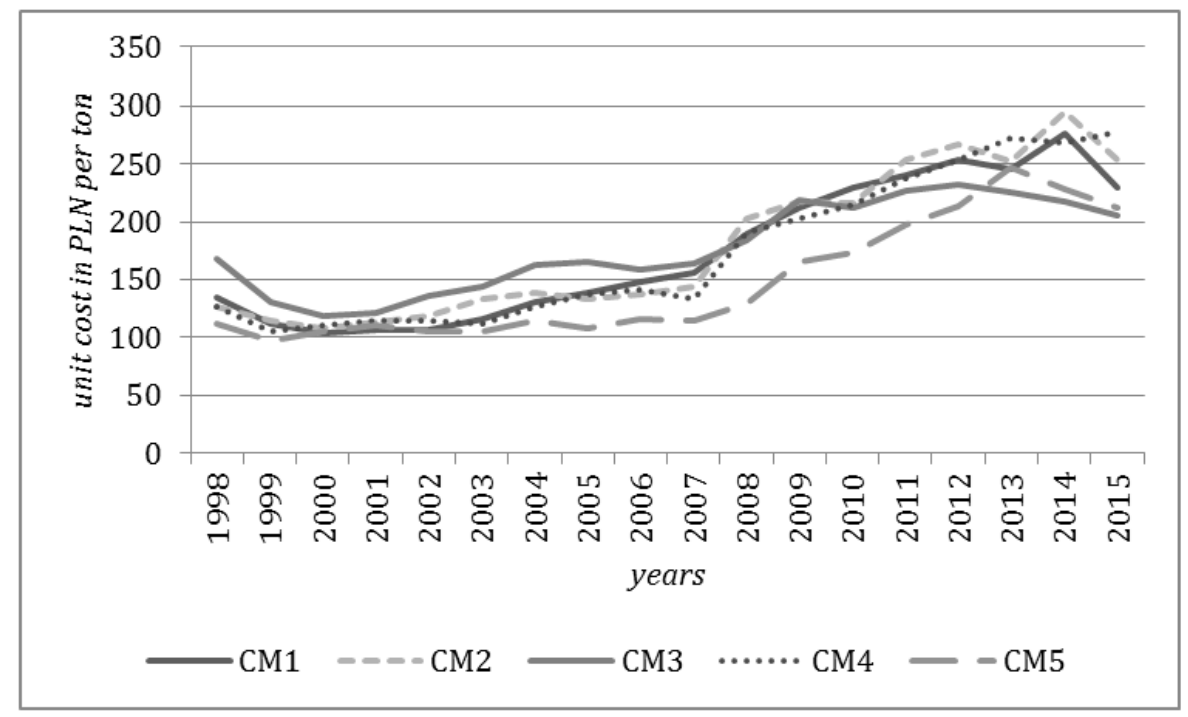

Figure 4. Unit costs in examined coalmines over the period 1998-2015 (PLN per ton). Source: own work.

Given the increase in unit costs and the decrease in production, employment restructuring has been insufficient. In all examined hard coalmines, a needed decrease in employment began in 2006 (Figure 5) and continued over the period of 2012 to 2015. 


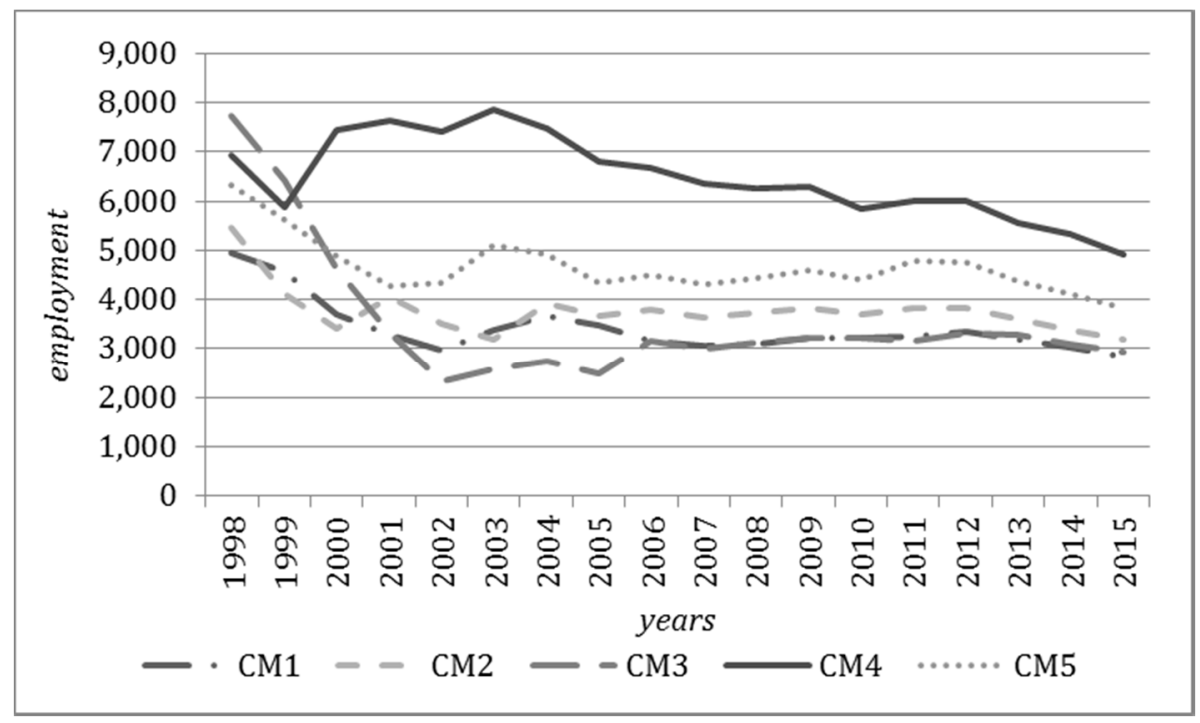

Figure 5. Employment in examined hard coalmines over the period 1998-2015. Source: own work.

\subsection{Total and Unit Costs in the Context of Infrastructure Parameters of the Examined Coal Mines}

Over the 18 years that were analyzed, the underground and ground infrastructure of the examined hard coalmines have been transformed due to market changes and the restructuring processes. Because of the decrease in production and costs, the number of longwalls decreased from 3-9 in 1998 to 3-5 in 2015 (Figure 6). The concentration of extraction was intended to increase productivity and reduce costs. However, because of an insufficient reduction in employment it was largely ineffective. Additionally, over the period studied, the length of longwalls has decreased (Figure 7). In 1998, the average length of a longwall ranged 200-250 m, and, in 2015, it ranged 180-230 m.

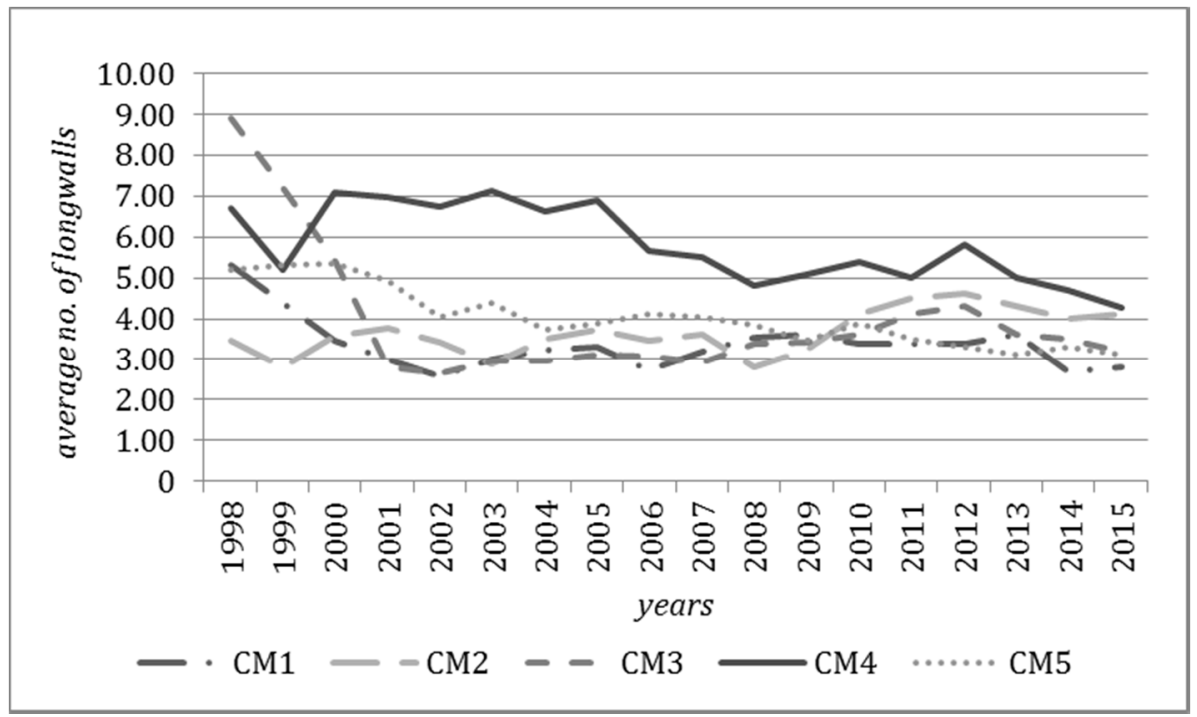

Figure 6. Average number of longwalls in the examined coalmines over the period 1998-2015. Source: own work. 


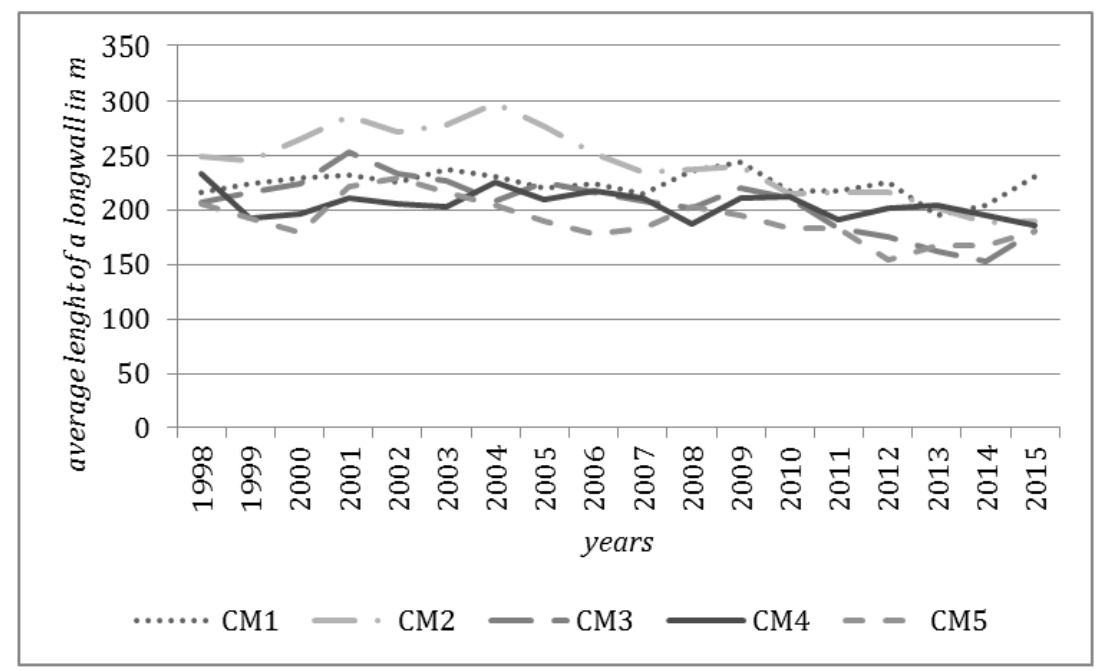

Figure 7. Average length of a longwall in the examined coalmines over the period 1998-2015 (m). Source: own work.

Until 2009, the concentration of excavation was not accompanied by an increase in the average daily longwall advance, which varied $3-5 \mathrm{~m}$ in all examined hard coalmines (Figure 8 ). The primary barrier to increasing the longwall advance was the presence of numerous geological faults in excavated deposits and the number of natural hazards, especially coal bumps and methane hazards that are typical of the majority of Polish hard coalmines (Turek, 2008). Since 2010, a large increase in the average daily longwall advance was observed in CM3 and CM5. In CM3, the increase was connected to the need to increase quality production and improve cost conditions, which could be achieved through equipment modernization, especially of the load bearing capacity of powered support and the installed power of cutter loaders. Additionally, the increase of the average daily longwall advance in CM3 was encouraged by the relatively low level of natural hazards. The relatively low level of natural hazards also allowed CM5 to increase its average daily longwall advance over the period 2009-2015, but the quality of its hard coal-especially its calorific value and sulfur content-was the lowest of the examined mines, and the longwall advance was increased to maximize the excavation, which resulted in decreased unit costs.

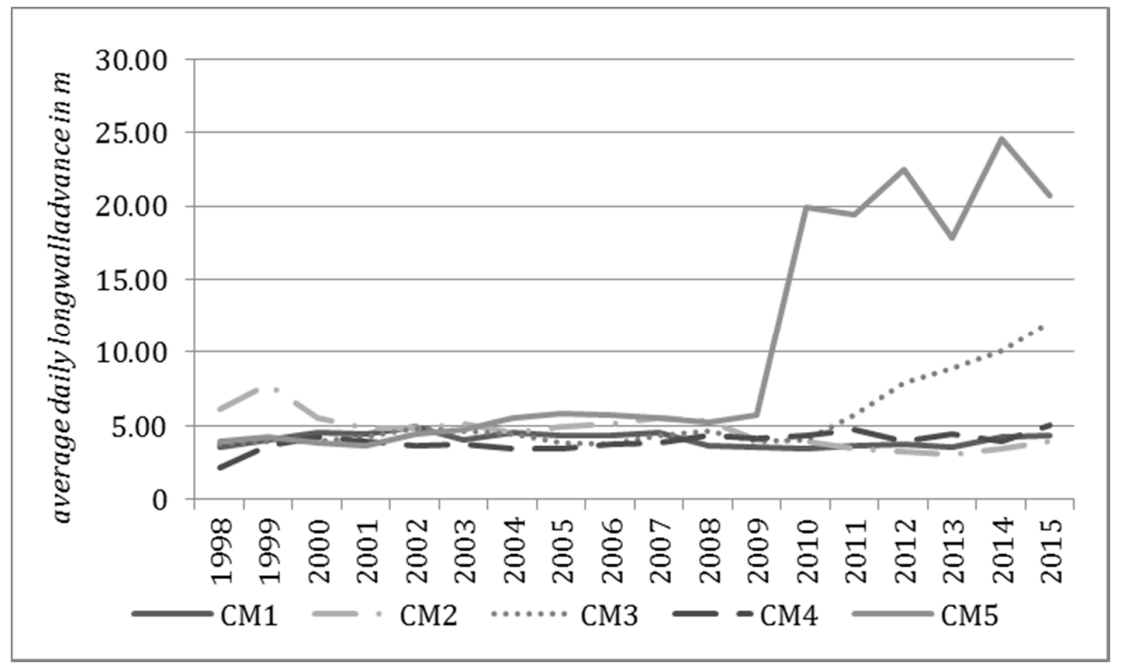

Figure 8. Average daily longwall advance in examined hard coalmines over the period 1998-2015 (m). Source: own work. 
Another determinant of the productivity and costs of hard coalmines is the average preparatory work advance (Figure 9). This parameter varied among the examined hard coalmines, and has increased considerably since 2010, especially in CM5. This change is in conjunction with the increase of the daily longwall advance and intensification of production. These changes demonstrate that there has been an increase in the production capacity of the best performing Polish hard coalmines, as expected by the restructuring process, which requires the selection of highly performing hard coalmines and the minimize unprofitable mines.

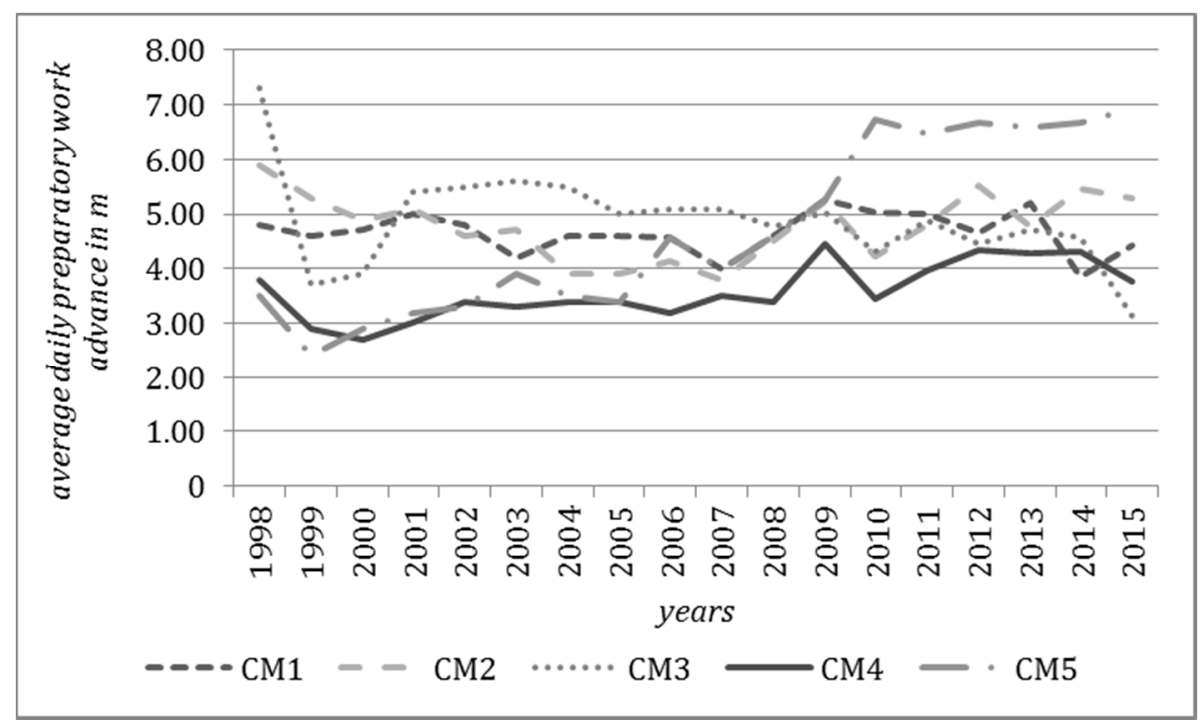

Figure 9. Average daily preparatory work advance in examined hard coalmines over the period 1998-2015 (m). Source: own work.

Additionally, the total production costs of hard coalmines were affected by infrastructure scope, which defines the model of a hard coalmine. This model included elements such as shafts, levels of exploitation and layers of exploitation. Generally, the greater the number of shafts, levels and layers are, the higher the total production costs are. As a result, a reduction in total production costs required at least a partial liquidation of infrastructure. A reduction in the number of shafts occurred in CM1, CM2 and CM4 (Figure 10). In the hard coalmines that experienced a considerable increase in production-CM3 and CM5 - the number of shafts increased. The number of levels in exploitation was constant in CM3, CM4 and CM5 but increased in CM1 and CM3 (Figure 11). Since 2009, the number of layers in exploitation rapidly increased in CM1, CM2, CM3 and CM4 (Figure 12). All observable changes in infrastructure confirmed the development of the highest performing Polish hard coalmines and that investment in their expansion should ensure the survival of the Polish hard coalmining industry.

In summary, all examined hard coalmines exhibited decreasing production and employment. Additionally, they were limiting aboveground and underground infrastructure wherever it was unnecessary to maintain and develop planned hard coal production capacity. Investments were (and are) obtained by the hard coalmines characterized by the highest production efficiency and the lowest unit costs. However, despite the efforts to improve the financial results of the hard coalmines, the total and unit costs increased over the period studied, which suggests that restructuring was insufficient and ineffective. To find the directions and ranges of total production costs determinants, in the following paragraphs, regression models for each examined hard coalmine were developed and their results were interpreted. 


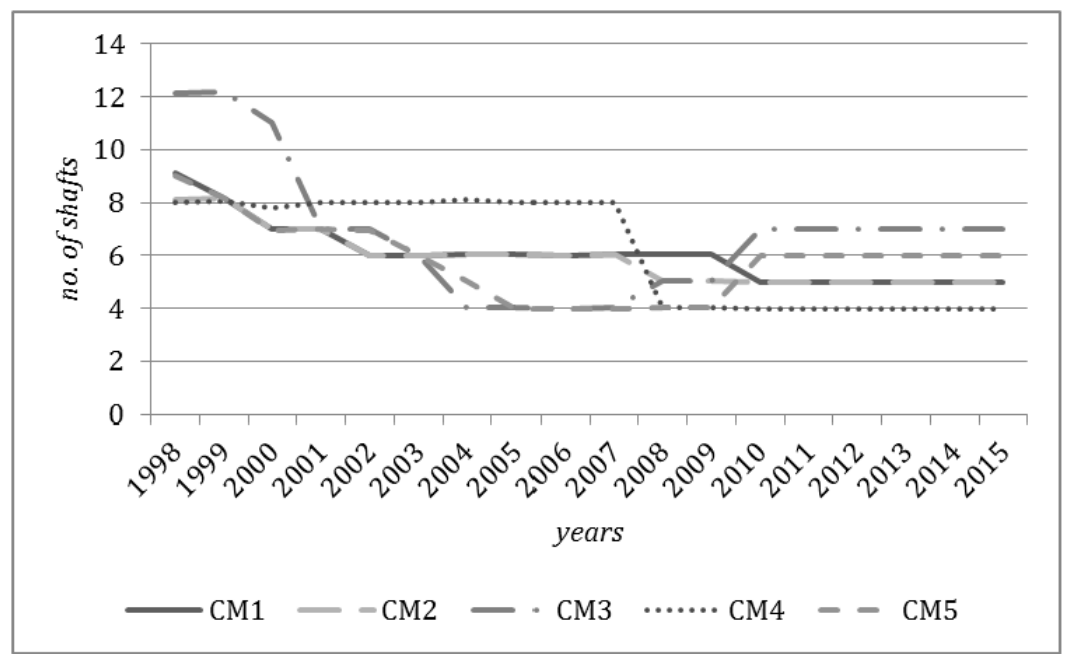

Figure 10. Number of shafts in examined hard coalmines over the period 1998-2015. Source: own work.

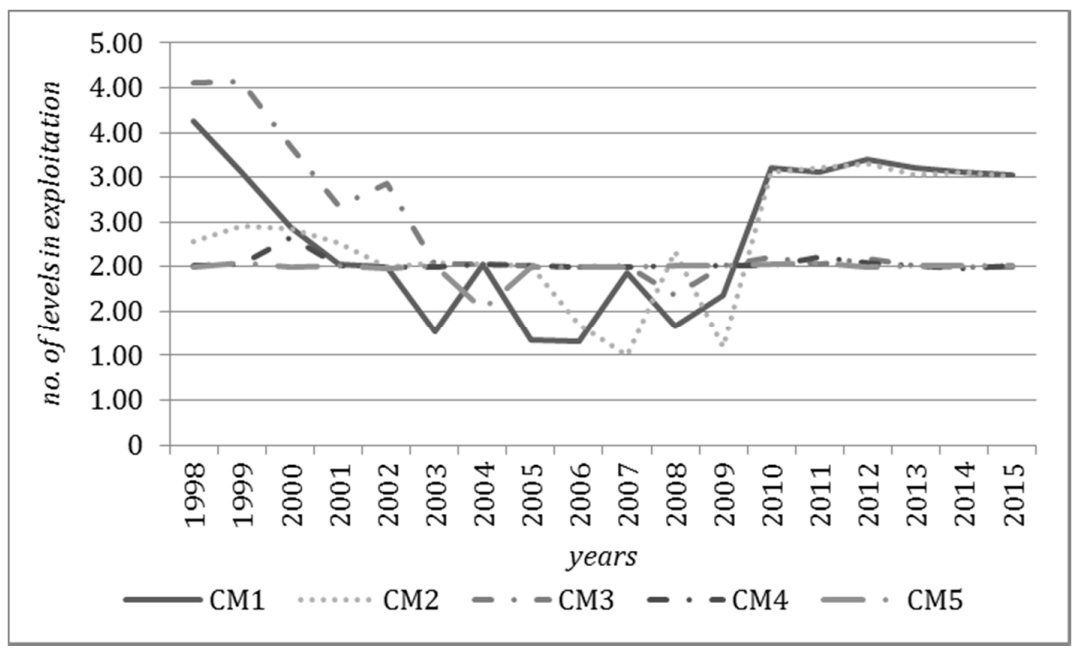

Figure 11. Number of levels in exploitation in examined hard coalmines over the period 1998-2015. Source: own work.

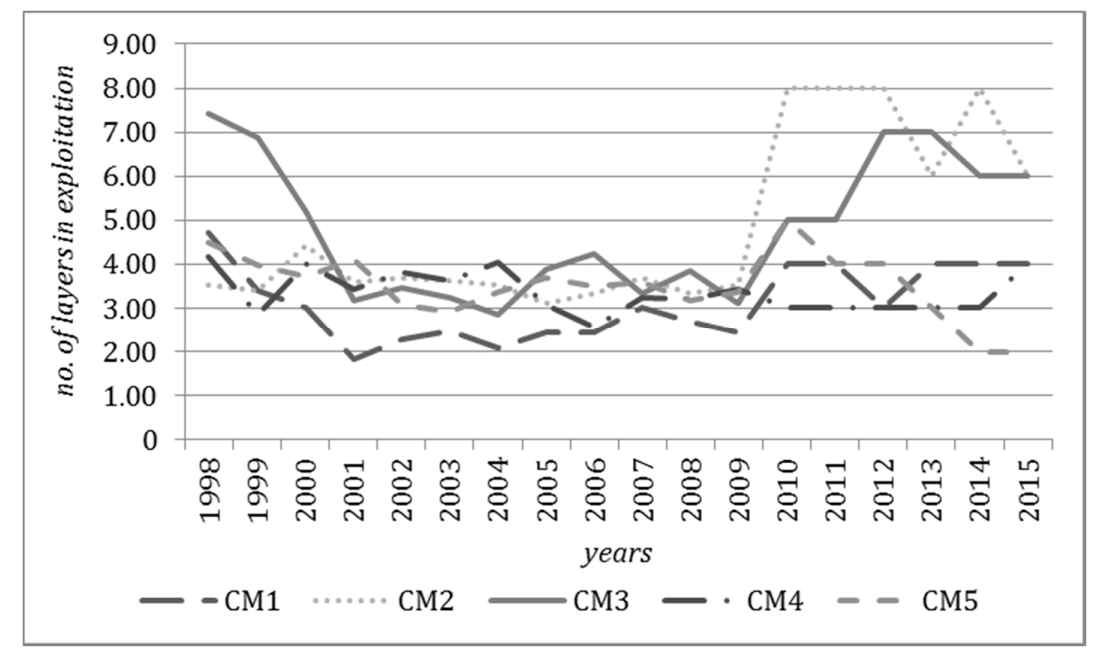

Figure 12. Number of layers in exploitation in examined hard coalmines over the period 1998-2015. Source: own work. 


\subsection{Dependence of the Total Production Costs on the Production and Infrastructure Parameters}

To evaluate the dependence of the total production costs on the production and infrastructure parameters, the Pearson's correlation coefficients have been calculated to estimate the direction and strength of the relationships between the total production costs and the independent variables. The majority of the important influences on total production costs are included in the regression model of each hard coalmine. The results are presented in Table 1.

Table 1. Correlation coefficients for total production costs in examined hard coalmines over the period 1998-2015.

\begin{tabular}{cccccc}
\hline Specification & \multicolumn{5}{c}{ Hard Coal Mines } \\
\cline { 2 - 6 } & CM1 & CM2 & CM3 & CM4 & CM5 \\
\hline Production & $-0.7756^{*}$ & $-0.8842^{*}$ & -0.0266 & $-0.6473^{*}$ & -0.4005 \\
Employment & -0.4301 & -0.2711 & -0.2268 & $-0.8297^{*}$ & -0.4143 \\
Average number of longwalls & -0.1276 & $0.6361^{*}$ & -0.1311 & $-0.7668^{*}$ & $-0.7757^{*}$ \\
No. of levels in exploitation & 0.4233 & $0.5573 *$ & $-0.5655^{*}$ & -0.2910 & 0.1393 \\
No. of layers in exploitation & $0.5407^{*}$ & $0.8152^{*}$ & 0.3599 & -0.2960 & -0.3364 \\
No. of shafts & $-0.7127^{*}$ & $-0.7999^{*}$ & -0.2427 & $-0.9314^{*}$ & -0.0778 \\
Average length of a longwall & -0.4066 & $-0.8621^{*}$ & $-0.7904^{*}$ & -0.4135 & $-0.6859^{*}$ \\
Average daily longwall advance & $-0.5490^{*}$ & $-0.7789 *$ & $0.5668^{*}$ & $0.5827^{*}$ & $0.9187^{*}$ \\
Average preparatory work advance & 0.0443 & 0.2987 & -0.1919 & $0.7803^{*}$ & $-0.7888^{*}$ \\
\hline & $* p<0.05(p-$ the significance level). & &
\end{tabular}

There were statistically significant correlations between the production level and the total production costs of three hard coalmines (CM1, CM2, CM5). For all hard coalmines, there were negative correlations between the production level and the total production costs. This indicates that, as production decreased, total production costs increased. Such regularity was economically irrational and resulted from two conditions. The first was high fixed costs, which were as much as $80 \%$ of total production costs. The second was an unjustified increase in salaries due to the demands of trade unions. Therefore, this increase occurred in isolation from the efficiency and productivity of the hard coalmining enterprises. As with the production level, there was a negative correlation between employment and the total production costs of all hard coalmines, although only one reached a statistically significant level (CM4). This strengthened the argument against the economically unjustified increase in salaries.

The correlations between the total production costs and the infrastructure parameters differed in significance, strength and direction. Moreover, the predicted relationship confirming the positive effect of production concentration on total production costs was observed in one hard coalmine (CM2). In the other mines, the total production costs increased as the number of longwalls decreased (in two of four hard coalmines there was a strong, statistically significant correlations). Additionally, in CM4, there was a positive statistically significant and strong to average correlation between total production costs and the number of levels in exploitation and the number of layers in exploitation. This positive statistically significant and strong to average correlation was also characteristic of CM1 but only between total production costs and the number of layers in exploitation. Based on the Pearson's correlation coefficients, a decrease in the number of shafts resulted in an increase in the total production costs of all examined hard coalmines (the relationship was statistically significant and strong for three hard coalmines).

Of the parameters defining the progress of production, the strongest significant correlations were between total production costs and the average daily longwall advance, but the directions of the correlations were not homogenous. The Pearson's correlation coefficients of three hard coalmines were positive (CM3, CM4, and CM5) but were negative for two hard coalmines (CM1 and CM2). The correlation between total production costs and the average length of the wall was negative for all mines, which means that a decrease in the length of the wall causes an increase in the total production 
costs. Similarly, there was a negative correlation between total production costs and the number of longwalls, which illustrated a lack of effects from production concentration (the Pearson's correlation coefficients for three mines were statistically significant). The correlation between total production costs and the average preparatory work advance was statistically significant for two hard coalmines. However, only one reflected an economically reasonable correlation with total production costs.

The above results showed that there were numerous statistically significant and strong correlations between total production costs and the production and infrastructure parameters. However, several were incompatible with economic regularities, which was a likely explanation for the ineffectiveness of the restructuring processes and the lack of improvement to efficiency. The majority of economically rational relationships were found in $\mathrm{CM} 2$.

In the second stage of the study, the regression models were used to estimate the effect of individual parameters on the total production costs of production in the examined hard coalmines. A full model included all independent variables and a limited model included only those that were significantly correlated with total production costs and resulted in a model that was a good fit to the data. The results are shown in Tables 2-6.

The regression models showed that the factors that had the greatest influence on total production costs for each hard coalmine are as follows:

- CM1: employment, number of levels in exploitation, number of shafts, and average daily longwall advance;

- CM2: production, number of shafts, average length of a longwall, and average preparatory work advance;

- CM3: employment, number of levels in exploitation, and average length of a longwall;

- CM4: employment, average number of longwalls, number of shafts, average daily longwall advance, and average preparatory work advance; and

- CM5: production, employment, average number of longwalls, average daily longwall advance, and average preparatory work advance.

Table 2. Regression models for CM1.

\begin{tabular}{|c|c|c|c|c|c|c|}
\hline Specification & \multicolumn{3}{|c|}{ Full Model } & \multicolumn{3}{|c|}{ Limited Model } \\
\hline $\mathrm{R}$ & \multicolumn{3}{|c|}{0.9542} & \multicolumn{3}{|c|}{0.9346} \\
\hline$R^{2}$ & \multicolumn{3}{|c|}{0.9105} & \multicolumn{3}{|c|}{0.8734} \\
\hline $\mathrm{R}^{2}$ adjusted & \multicolumn{3}{|c|}{0.8099} & \multicolumn{3}{|c|}{0.8344} \\
\hline $\mathrm{F}$ & \multicolumn{3}{|c|}{$F(9.8)=9.0496$} & \multicolumn{3}{|c|}{$F(4.13)=22.426$} \\
\hline$p$ & \multicolumn{3}{|c|}{$p<0.0025$} & \multicolumn{3}{|c|}{$p<0.00001$} \\
\hline SE & \multicolumn{3}{|c|}{26.12} & \multicolumn{3}{|c|}{24.376} \\
\hline \multirow{2}{*}{ Variables } & \multicolumn{3}{|c|}{ Parameters } & \multicolumn{3}{|c|}{ Parameters } \\
\hline & $\mathbf{b}^{* *}$ & $\mathbf{b}$ & $p$ & $\mathbf{b}^{* *}$ & b & $p$ \\
\hline Production & 0.1832 & 0.0001 & 0.6302 & - & - & - \\
\hline Employment & -0.5067 & -0.06 & 0.2265 & -0.2062 & -0.230 & 0.4394 \\
\hline Average number of longwalls & 0.2406 & 22.35 & 0.5969 & - & - & - \\
\hline No. of levels in exploitation & 0.4548 & 34.45 & 0.0915 & 0.3924 & 29.73 & 0.0074 \\
\hline No. of layers in exploitation & -0.1860 & -13.22 & 0.5628 & - & - & - \\
\hline No. of shafts & -0.5500 & -28.78 & 0.1432 & -0.5423 & -28.48 & 0.0411 \\
\hline Average length of a longwall & -0.1508 & -0.77 & 0.5284 & - & - & - \\
\hline Average daily longwall advance & -0.6009 & -80.08 & 0.1218 & -0.4201 & -55.99 & 0.0031 \\
\hline Average preparatory work advance & -0.2204 & -34.84 & 0.1768 & - & - & - \\
\hline
\end{tabular}


Table 3. Regression models for CM2.

\begin{tabular}{|c|c|c|c|c|c|c|}
\hline Specification & \multicolumn{3}{|c|}{ Full Model } & \multicolumn{3}{|c|}{ Limited Model } \\
\hline $\mathrm{R}$ & \multicolumn{3}{|c|}{0.9831} & \multicolumn{3}{|c|}{0.9713} \\
\hline $\mathrm{R}^{2}$ & \multicolumn{3}{|c|}{0.9665} & \multicolumn{3}{|c|}{0.9434} \\
\hline $\mathrm{R}^{2}$ adjusted & \multicolumn{3}{|c|}{0.9288} & \multicolumn{3}{|c|}{0.9126} \\
\hline $\mathrm{F}$ & \multicolumn{3}{|c|}{$\mathrm{F}(9.8)=25.635$} & \multicolumn{3}{|c|}{$F(6.11)=30.598$} \\
\hline$p$ & \multicolumn{3}{|c|}{$p<0.00006$} & \multicolumn{3}{|c|}{$p<0.00000$} \\
\hline SE & \multicolumn{3}{|c|}{17.125} & \multicolumn{3}{|c|}{18.967} \\
\hline \multirow{2}{*}{ Variables } & \multicolumn{3}{|c|}{ Parameters } & \multicolumn{3}{|c|}{ Parameters } \\
\hline & $\mathbf{b}^{* *}$ & $\mathbf{b}$ & $p$ & $\mathbf{b}^{* *}$ & $\mathbf{b}$ & $p$ \\
\hline Production & -0.1868 & -0.0000 & 0.4345 & -0.2359 & 0.00 & 0.3488 \\
\hline Employment & 0.1296 & 0.02 & 0.1837 & - & - & - \\
\hline Average number of longwalls & 0.0783 & 9.30 & 0.7807 & -0.0706 & -8.38 & 0.7986 \\
\hline No. of levels in exploitation & 0.0636 & 6.19 & 0.6109 & 0.0918 & 3.06 & 0.6595 \\
\hline No. of layers in exploitation & 0.0316 & 1.05 & 0.8792 & - & - & - \\
\hline No. of shafts & -0.5238 & -31.84 & 0.0971 & -0.0345 & -2.10 & 0.8573 \\
\hline Average length of a longwall & -0.2809 & -0.54 & 0.1661 & -0.4543 & -0.88 & 0.0220 \\
\hline Average daily longwall advance & -0.0172 & -0.95 & 0.9575 & - & - & - \\
\hline Average preparatory work advance & 0.1703 & 17.72 & 0.1841 & -0.3667 & -20.21 & 0.2111 \\
\hline
\end{tabular}

$\mathrm{b}^{* *}$-standardized coefficient $\mathrm{b}$.

Table 4. Regression models for CM3.

\begin{tabular}{|c|c|c|c|c|c|c|}
\hline Specification & \multicolumn{3}{|c|}{ Full Model } & \multicolumn{3}{|c|}{ Limited Model } \\
\hline $\mathrm{R}$ & \multicolumn{3}{|c|}{0.9014} & \multicolumn{3}{|c|}{0.8754} \\
\hline $\mathrm{R}^{2}$ & \multicolumn{3}{|c|}{0.8125} & \multicolumn{3}{|c|}{0.7663} \\
\hline $\mathrm{R}^{2}$ adjusted & \multicolumn{3}{|c|}{0.6016} & \multicolumn{3}{|c|}{0.6945} \\
\hline $\mathrm{F}$ & \multicolumn{3}{|c|}{$\mathrm{F}(9.8)=3.8528$} & \multicolumn{3}{|c|}{$\mathrm{F}(4.13)=10.661$} \\
\hline$p$ & \multicolumn{3}{|c|}{$p<0.0354$} & \multicolumn{3}{|c|}{$p<0.00047$} \\
\hline SE & \multicolumn{3}{|c|}{24.551} & \multicolumn{3}{|c|}{21.500} \\
\hline \multirow{2}{*}{ Variables } & \multicolumn{3}{|c|}{ Parameters } & \multicolumn{3}{|c|}{ Parameters } \\
\hline & $\mathbf{b}^{* *}$ & $\mathbf{b}$ & $p$ & $b^{* *}$ & $\mathbf{b}$ & $p$ \\
\hline Production & 0.2672 & 0.00 & 0.6975 & - & - & - \\
\hline Employment & -0.4726 & -0.01 & 0.6246 & 0.4218 & 0.0118 & 0.2414 \\
\hline Average number of longwalls & 0.4474 & 10.50 & 0.7020 & - & - & - \\
\hline No. of levels in exploitation & -1.0413 & -55.25 & 0.0926 & -0.7399 & -39.26 & 0.0530 \\
\hline No. of layers in exploitation & 0.2692 & 6.69 & 0.5756 & - & - & - \\
\hline No. of shafts & 0.2976 & 4.47 & 0.6289 & - & - & - \\
\hline Average length of a longwall & -0.4238 & -0.63 & 0.4801 & -0.5845 & -0.8701 & 0.0630 \\
\hline Average daily longwall advance & -0.2534 & -3.94 & 0.7390 & -0.0324 & -0.5033 & 0.8984 \\
\hline Average preparatory work advance & 0.1757 & 7.645 & 0.5728 & - & - & - \\
\hline
\end{tabular}

Among the production parameters, the most impactful was employment, which was a significant predictor for four hard coalmines. This illustrated the importance of this factor and indicated the need to correct its relationship with total production costs. Among the static infrastructure parameters, the most important were the number of levels in exploitation, the number of shafts and the average number of longwalls. Finally, the most important of the dynamic infrastructure parameters were the average daily longwall advance and the average preparatory work advance. 
Table 5. Regression models for CM4.

\begin{tabular}{|c|c|c|c|c|c|c|}
\hline Specification & \multicolumn{3}{|c|}{ Full Model } & \multicolumn{3}{|c|}{ Limited Model } \\
\hline $\mathrm{R}$ & \multicolumn{3}{|c|}{0.9777} & \multicolumn{3}{|c|}{0.9756} \\
\hline$R^{2}$ & \multicolumn{3}{|c|}{0.9559} & \multicolumn{3}{|c|}{0.9518} \\
\hline $\mathrm{R}^{2}$ adjusted & \multicolumn{3}{|c|}{0.9034} & \multicolumn{3}{|c|}{0.9317} \\
\hline $\mathrm{F}$ & \multicolumn{3}{|c|}{$\mathrm{F}(9.8)=19.284$} & \multicolumn{3}{|c|}{$\mathrm{F}(5.12)=47.414$} \\
\hline$p$ & \multicolumn{3}{|c|}{$p<0.00017$} & \multicolumn{3}{|c|}{$p<0.0000$} \\
\hline SE & \multicolumn{3}{|c|}{19.727} & \multicolumn{3}{|c|}{16.843} \\
\hline \multirow{2}{*}{ Variables } & \multicolumn{3}{|c|}{ Parameters } & \multicolumn{3}{|c|}{ Parameters } \\
\hline & $\mathbf{b}^{* *}$ & $\mathbf{b}$ & $p$ & $\mathbf{b}^{* *}$ & $\mathbf{b}$ & $p$ \\
\hline Production & -0.1385 & -0.0000 & 0.6418 & - & - & - \\
\hline Employment & -0.4793 & -0.0364 & 0.1599 & -0.5519 & -0.0420 & 0.2010 \\
\hline Average number of longwalls & 0.4219 & 28.72 & 0.1090 & 0.3571 & 24.31 & 0.0074 \\
\hline No. of levels in exploitation & -0.0417 & -34.39 & 0.6828 & - & - & - \\
\hline No. of layers in exploitation & 0.0068 & 0.9132 & 0.9471 & - & - & - \\
\hline No. of shafts & -0.3964 & -12.50 & 0.1015 & -0.4220 & -13.31 & 0.0226 \\
\hline Average length of a longwall & 0.0795 & 0.3992 & 0.5492 & - & - & - \\
\hline Average daily longwall advance & 0.3537 & 36.90 & 0.1976 & 0.2077 & 21.67 & 0.0723 \\
\hline Average preparatory work advance & 0.3070 & 38.15 & 0.0819 & 0.3251 & 40.39 & 0.0145 \\
\hline
\end{tabular}

$b^{* *}$-standardized coefficient $b$.

Table 6. Regression models for CM5.

\begin{tabular}{|c|c|c|c|c|c|c|}
\hline Specification & \multicolumn{3}{|c|}{ Full Model } & \multicolumn{3}{|c|}{ Limited Model } \\
\hline $\mathrm{R}$ & \multicolumn{3}{|c|}{0.9761} & \multicolumn{3}{|c|}{0.9611} \\
\hline $\mathrm{R}^{2}$ & \multicolumn{3}{|c|}{0.9527} & \multicolumn{3}{|c|}{0.9237} \\
\hline $\mathrm{R}^{2}$ adjusted & \multicolumn{3}{|c|}{0.8995} & \multicolumn{3}{|c|}{0.9237} \\
\hline $\mathrm{F}$ & \multicolumn{3}{|c|}{$\mathrm{F}(9.8)=17.898$} & \multicolumn{3}{|c|}{$\mathrm{F}(5.12)=29.080$} \\
\hline$p$ & \multicolumn{3}{|c|}{$p<0.00022$} & \multicolumn{3}{|c|}{$p<0.00000$} \\
\hline SE & \multicolumn{3}{|c|}{16.158} & \multicolumn{3}{|c|}{16.746} \\
\hline \multirow{2}{*}{ Variables } & \multicolumn{3}{|c|}{ Parameters } & \multicolumn{3}{|c|}{ Parameters } \\
\hline & $\mathbf{b}^{* *}$ & $\mathbf{b}$ & $p$ & $b^{* *}$ & b & $p$ \\
\hline Production & -0.2490 & -0.0000 & 0.1073 & -0.2414 & -0.0000 & 0.0300 \\
\hline Employment & 0.0920 & 0.0081 & 0.6408 & 0.1562 & 0.0137 & 0.1725 \\
\hline Average number of longwalls & -0.7014 & -48.36 & 0.0161 & -0.3996 & -27.55 & 0.0300 \\
\hline No. of levels in exploitation & 0.1445 & 63.74 & 0.1659 & - & - & - \\
\hline No. of layers in exploitation & 0.0915 & 6.12 & 0.4463 & - & - & - \\
\hline No. of shafts & 0.2042 & 7.07 & 0.5112 & - & - & - \\
\hline Average length of a longwall & -0.1554 & -0.4028 & 0.3993 & - & - & - \\
\hline Average daily longwall advance & 0.4506 & 2.91 & 0.2480 & 0.7741 & 5.00 & 0.0307 \\
\hline Average preparatory work advance & 0.1863 & 4.97 & 0.5958 & 0.1639 & 4.37 & 0.5513 \\
\hline
\end{tabular}

\section{Discussion}

The results showed that employment and production were negatively correlated with total production costs, which failed to support $\mathrm{H} 1$ : The reduction in employment (A) and production (B) causes a decrease in total production costs. Such economically irrational regularity resulted from the high proportion of fixed costs in the total production costs. The importance of this conclusion is emphasized by the regression models that indicated that employment and production levels were crucial determinants of total production costs. Therefore, total production costs were influenced by irrational economic relationships that had a negative impact on the financial performance of hard coalmines.

The relationships between the total production costs and the production concentration varied among parameters. Only one of hard coalmines showed a positive and significant correlation between 
the total production costs and the number of longwalls. In CM4 and CM5, the number of longwalls had an extreme negative effect on total production costs. It is an important predictor in the regression models and had a strong negative correlation with the costs of production. The parameter, the length of a longwall, was negatively correlated with total production costs for all hard coalmines. The correlation was statistically significant for three of the hard coalmines. From the above observations, there was partial support for $\mathrm{H} 2$ : The concentration of mining production (demonstrating mostly in longwalls reducing) (A) and increasing of the length of a longwall (B) influences the total production costs reduction.

Additionally, we rejected H3: Reducing the number of levels (A), layers (B), and shafts (C) enables the total production costs decrease. Economically rational relationships (positive correlations) between the number of levels and layers and the total production costs were present only in the case of CM2. However, the regression models showed that their impact on the total production costs was irregular and not of primary importance (the most important parameters are: the average length of a longwall and average number of longwalls).

The analyses of the dynamic parameters led to different results for each parameter. In three of the five hard coalmines, the relationship between the total production costs and the average daily longwall advance matched the prediction. The relationship between the total production costs and the average preparatory work advance matched the prediction for one of the five examined hard coalmines (CM4). We rejected the fourth research hypothesis, H4: Increase in dynamic infrastructure parameters improving the productivity (average daily longwall advance) (A) and average preparatory work advance (B) increases the total production costs.

In summary, although the regression models are well-fitted to the data and could statistically forecast the total production costs of the examined hard coalmines, they confirmed the presence economically irrational relationships. Therefore, we concluded that the restructuring process was ineffective because, for example, limiting the scale of infrastructure did not reduce total production costs. The variable of most concern was employment. It was a strong predictor of total production costs in the regression models and was negatively correlated with the total production costs of all the examined hard coalmines. Therefore, employment represented a significant barrier to financial success. This assertion was also confirmed by the results of the analyses of CM2. In this hard coalmine, there were the highest number of predicted relationships between total production costs and the production and technical parameters. Additionally, its financial performance was superior to those of the other examined hard coalmines.

As it was mentioned, the Polish coalmining is under deep restructuring now and supporting the examined mines is one of the most important restructuring actions. These mines were evaluated as the prospective ones, and have been included in the structure of the newly established mining enterprise. The inefficient coalmines were liquidated or will be liquidated by 2018. Further restructuring of survived coalmines have to include: (1) increasing productivity that can be achieved through improvement of employment structure (increasing the share of production employees in the total employment); (2) introducing the motivation system in which the salaries will be partly dependent on productive and financial results; (3) increasing current and future investment expenditures in the most efficient activities; and (4) reviewing the infrastructure for its usability. The mentioned activities should also improve inappropriate relationships—described in the article-between the production and infrastructure relationships and the total costs of production.

The presented research has some limitation worth of mentioning. It includes only five coalmines operating in Poland and it was conducted using the case study methodology. Moreover, it does not include all conditions influencing the total cost of mining production. We did not consider: geological conditions, rock types, resources' reserves as well as the competences and skills of workers because we treated them as the necessary conditions required for extraction and fulfilled in all examined coalmines in advance. Nevertheless, the research contributes to mining economics development in the aspect of 
cost determinants and cost management in hard coalmining. It also provides practical implications for examined coalmines and extractive industry in Poland.

\section{Conclusions}

- The relationships between the production parameters (employment and production level) in examined coalmines are economically irrational. The total production costs increase even when the employment and production level decreases.

- The concentration of mining production (demonstrating mostly in longwalls reducing) and increasing of the length of a longwall influences the total production costs reduction only in some examined coalmines.

- Increase in dynamic infrastructure parameters improving the productivity (average daily longwall advance) and average preparatory work advance does not increase the total production costs.

- The examined hard coalmines should restore economically rational relationships between technical and production variables and the total production cost with a focus on the parameter of employment.

- The concentration of production and the efforts to improve productivity will not be efficient if employment and wages-which represent $60 \%$ of the total production costs-are not lowered.

- The use of the inappropriate approach to wages is due to the prioritization of human resources in Polish hard coalmining enterprises, which is strengthened by the nonnegotiable demands of the trade unions.

- Further restructuring of survived coalmines have to include: (1) increasing productivity, which can be achieved through improvement of employment structure (increasing the share of production employees in the total employment); (2) introducing the motivation system in which the salaries will be partly depended on productive and financial results; (3) increasing current and future investment expenditures in the most efficient activities; and (4) reviewing the infrastructure for its usability.

Acknowledgments: The authors would like to express gratitude to the Director of the Institute of Economy and Computer Sciences for financing the cost of article preparation from Statutory research Nos. BK/221-ROZ-1/2015 and BK-212/ROZ1/2017.

Author Contributions: Izabela Jonek-Kowalska designed the research conception, prepared literature studies and conducted the research. Marian Turek took part in the literature studies, hypothesis formulating and result description.

Conflicts of Interest: The authors declare no conflict of interest.

\section{References}

1. Michalak, A. The cost of capital in the effectiveness assessment of financial management in a company. Oecon. Copernic. 2016, 7, 317-329. [CrossRef]

2. Nawrocki, T. The use of fuzzy logic in the enterprises business efficiency assessment. In The Essence and Measurement of Organizational Efficiency; Dudycz, T., Osbert-Pociecha, G., Brycz, B., Eds.; Springer Proceedings in Business and Economics, Poland; Springer: Cham, Switzerland, 2015; pp. 229-248.

3. Zieliński, M. Efektywność-Ujęcie ekonomiczne i społeczne. Zesz. Naukowe Politech. Śląskiej Ser. Organ. Zarz. 2013, 66, 137-148.

4. Bluszcz, A. European economies in terms of energy dependence. Qual. Quant. 2016, 2, 1-18. [CrossRef] [PubMed]

5. Chong, T.; Yi, S.; Heng, C. Application of set pair analysis method on occupational hazard of coal mining. Saf. Sci. 2017, 92, 10-16. [CrossRef]

6. Karan, S.K.; Samadder, S.R. Reduction of spatial distribution of risk factors for transportation of contaminants released by coal mining activities. J. Environ. Manag. 2016, 180, 280-290. [CrossRef] [PubMed] 
7. Wang, S.; Li, X.; Wang, D. Mining-induced void distribution and application in the hydro-thermal investigation and control of an underground coal fire: A case study. Process Saf. Environ. Prot. 2016, 102, 734-756. [CrossRef]

8. Wolny, M. The Concept of Risk Dominance in MADM with No Inter-Criteria Information. Mult. Criteria Decis. Mak. 2015, 10, 185-194.

9. Trojnar, A.; Więckol-Ryk, A.; Niemiec, B. Koszty profilaktyki zagrożenia tąpaniami w kopalniach węgla kamiennego. Wiad. Górnicze 2014, 4, 209-220.

10. Michalak, A.; Turek, M. A method of pricing an asset lost in a mining catastrophe. Arch. Min. Sci. 2012, 57, 799-814.

11. Brodny, J. Analysis of operation of new construction of the frictional joint with the resistance wedge. Arch. Min. Sci. 2012, 57, 209-227.

12. Liu, H.; Cheng, Y. The elimination of coal and gas outburst disasters by long distance lower protective seam mining combined with stress-relief gas extraction in the Huaibei coal mine area. J. Nat. Gas Sci. Eng. 2015, 27, 346-353. [CrossRef]

13. Hendryx, M. The public health impacts of surface coal mining. Extr. Ind. Soc. 2015, 2, 820-826. [CrossRef]

14. Hota, P.; Behera, B. Coal mining in Odisha: An analysis of impacts on agricultural production and human health. Extr. Ind. Soc. 2015, 2, 683-693. [CrossRef]

15. Álvarez, R.; Ordóñez, A.; De Miguel, E.; Loredo, C. Prediction of the flooding of a mining reservoir in NW Spain. J. Environ. Manag. 2015, 184, 219-228. [CrossRef] [PubMed]

16. Yuan, L. Control of coal and gas outbursts in Huainan mines in China. J. Rock Mech. Geotech. Eng. 2016, 8, 559-567. [CrossRef]

17. Verma, A.; Olateju, B.; Kumar, A. Greenhouse gas abatement costs of hydrogen production from underground coal gasification. Energy 2016, 85, 556-568. [CrossRef]

18. Singh, A.K.; Kumar, J. Fugitive Methane Emissions from Indian Coal Mining and Handling Activities: Estimates, Mitigation and Opportunities for its Utilization to Generate Clean Energy. Energy Procedia 2016, 90, 336-348. [CrossRef]

19. Zhang, J.; Zhang, Q.; Spearing, A.J.S.; Miao, X.; Guo, S.; Sun, Q. Green coal mining technique integrating mining-dressing-gas draining-backfilling-mining. Int. J. Min. Sci. Technol. 2016, 12, 17-27. [CrossRef]

20. Cui, L.; Cheng, F.; Zhou, J. Preparation of high purity $\mathrm{AlCl}_{3} \cdot 6 \mathrm{H}_{2} \mathrm{O}$ crystals from coal mining waste based on iron (III) removal using undiluted ionic liquids. Sep. Purif. Technol. 2016, 167, 45-54. [CrossRef]

21. Ściążko, M.; Chmielniak, T. Zero-Emisyjny Kompleks Energio-Chemiczny-Unikalny Przykład Działania Proekologicznego Wykorzystujacego Węiel Kamienny; Szkoła Eksploatacji Podziemnej: Kraków, Poland, 2010; pp. 36-50.

22. Fei, W.B.; Li, Q.; Wei, C.; Song, R.R.; Jing, M.; Li, X.C. Interaction analysis for $\mathrm{CO}_{2}$ geological storage and underground coal mining in Ordos Basin, China. Eng. Geol. 2015, 196, 194-209. [CrossRef]

23. Burchart-Korol, D.; Fugiel, A.; Czaplicka-Kolarz, K.; Turek, M. Model of environmental life cycle assessment for coal mining operations. Sci. Total Environ. 2016, 562, 61-72. [CrossRef] [PubMed]

24. Calvo, J.A.P.; Pérez, A.M.J. Optimal extraction policy when the environmental and social costs of the opencast coal mining activity are internalized: Mining District of the Department of El Cesar (Colombia) case study. Energy Econ. 2016, 59, 159-166. [CrossRef]

25. Krzemień, A.; Sánchez, A.S.; Fernández, P.R.; Zimmermann, K.; Coto, F.G. Towards sustainability in underground coal mine closure contexts: A methodology proposal for environmental risk management. J. Clean. Prod. 2016, 139, 1044-1056. [CrossRef]

26. Salmi, E.F.; Nazem, M.; Karakus, M. The effect of rock mass gradual deterioration on the mechanism of post-mining subsidence over shallow abandoned coal mines. Int. J. Rock Mech. Min. Sci. 2017, 91, 59-71. [CrossRef]

27. Yaylac1, E.D.; Düzgün, H.S. Indicator-based sustainability assessment for the mining sector plans: Case of Afşin-Elbistan Coal Basin. Int. J. Coal Geol. 2016, 165, 190-200. [CrossRef]

28. Yu, X. Coal mining and environmental development in southwest China. Environ. Dev. 2017, 21, 77-86. [CrossRef]

29. Bluszcz, A.; Kijewska, A. Challenges of sustainable development in the mining and metallurgy sector in Poland. Metalurgija 2014, 54, 441-444. 
30. Bustos, B.; Folchi, M.; Fragkou, M. Coal mining on pastureland in Southern Chile; Challenging recognition and participation as guarantees for environmental justice. Geoforum 2017, 84, 292-304. [CrossRef]

31. Bao, N.; Wu, L.; Ye, B.; Yang, K.; Zhou, W. Assessing soil organic matter of reclaimed soil from a large surface coal mine using a field spectroradiometer in laboratory. Geoderma 2017, 288, 47-55. [CrossRef]

32. De Klerk, A.R.; Oberholster, P.J.; van Wyk, J.H.; Truter, J.C.; Schaefer, L.M.; Botha, A.-M. The effect of rehabilitation measures on ecological infrastructure in response to acid mine drainage from coal mining. Ecol. Eng. 2016, 95, 463-474. [CrossRef]

33. Lechner, A.M.; Kassulke, O.; Unger, C. Spatial assessment of open cut coal mining progressive rehabilitation to support the monitoring of rehabilitation liabilities. Resour. Policy 2016, 50, 234-243. [CrossRef]

34. Lima, A.T.; Mitchell, K.; O'Connell, D.W.; Verhoeven, J.; Van Cappellen, P. The legacy of surface mining: Remediation, restoration, reclamation and rehabilitation. Environ. Sci. Policy 2016, 66, 227-233. [CrossRef]

35. Dong, J.; Cheng, Y.-P.; Chang, T.-Y.; Zhang, J.-J.; Guo, S.-F. Coal mine methane control cost and full cost: The case of the Luling Coal Mine, Huaibei coalfield, China. J. Nat. Gas Sci. Eng. 2015, 26, 290-302. [CrossRef]

36. Frantál, B. Living on coal: Mined-out identity, community displacement and forming of anti-coal resistance in the Most region, Czech Republic. Resour. Policy 2016, 49, 385-393. [CrossRef]

37. Fugiel, A.; Burchart-Korol, D.; Czaplicka-Kolarz, K.; Smoliński, A. Environmental impact and damage categories caused by air pollution emissions from mining and quarrying sectors of European countries. J. Clean. Prod. 2017, 143, 159-168. [CrossRef]

38. McDuie-Ra, D.; Kikon, D. Tribal communities and coal in Northeast India: The politics of imposing and resisting mining bans. Energy Policy 2016, 99, 261-269. [CrossRef]

39. Mishra, S.K.; Hitzhusen, F.J.; Sohngen, B.L.; Guldmann, J.M. Costs of abandoned coal mine reclamation and associated recreation benefits in Ohio. J. Environ. Manag. 2012, 100, 52-58. [CrossRef] [PubMed]

40. Zafrilla, J.R. The mining industry under the thumb of politicians: The environmental consequences of the Spanish Coal Decree. J. Clean. Prod. 2014, 84, 715-722. [CrossRef]

41. Valero, A.; Domínguez, A.; Valero, B. Exergy cost allocation of by-products in the mining and metallurgical industry. Resour. Conserv. Recycl. 2015, 102, 128-142. [CrossRef]

42. Vegas, I.; Cano, M.; Arribas, I.; Frías, M.; Rodríguez, O. Physical-mechanical behavior of binary cements blended with thermally activated coal mining waste. Constr. Build. Mater. 2015, 99, 169-174. [CrossRef]

43. Limanskiy, A.V.; Vasilyeva, M.A. Using of low-grade heat mine water as a renewable source of energy in coal-mining regions. Ecol. Eng. 2016, 91, 41-43. [CrossRef]

44. Oliveira, C.M.; Machado, C.M.; Duarte, G.W.; Peterson, M. Beneficiation of pyrite from coal mining. J. Clean. Prod. 2016, 139, 821-827. [CrossRef]

45. Cardoso, A. Behind the life cycle of coal: Socio-environmental liabilities of coal mining in Cesar, Colombia. Ecol. Econ. 2015, 120, 71-82. [CrossRef]

46. Fernández, S.; Poschenrieder, C.; Marcenò, C.; Gallego, J.R.; Jiménez-Gámez, D.; Bueno, A.; Afif, E. Phytoremediation capability of native plant species living on $\mathrm{Pb}-\mathrm{Zn}$ and $\mathrm{Hg}$-As mining wastes in the Cantabrian range, north of Spain. J. Geochem. Explor. 2017, 174, 10-20. [CrossRef]

47. Galloux, J.; Chekli, L.; Phuntsho, S.; Tijing, L.D.; Jeong, S.; Zhao, Y.X.; Gao, B.Y.; Park, S.H.; Shon, H.K. Coagulation performance and floc characteristics of polytitanium tetrachloride and titanium tetrachloride compared with ferric chloride for coal mining wastewater treatment. Sep. Purif. Technol. 2015, 152, 94-100. [CrossRef]

48. Norman, H. Coal Mining and Coal Seam Gas on Gomeroi country: Sacred lands, economic futures and shifting alliances. Energy Policy 2016, 99, 242-251. [CrossRef]

49. Sorin, M.; Mirela, I.; Diana, C. Considerations on the Cost of Electricity Production in the Context of Integration Operating Activities Underground and Production of Coal in Thermal Power Stations Electricity in the Jiu Valley Mining Area. Procedia Econ. Financ. 2017, 23, 371-377. [CrossRef]

50. Gorczyńska, A. The impact of the crisis on the course of cross-border consolidation processes. Equilibrum 2011, 6, 17-21.

51. Ma, J.; Dai, H. A methodology to construct warning index system for coal mine safety based on collaborative management. Saf. Sci. 2017, 93, 86-95. [CrossRef]

52. Korski, J.; Tobór-Osadnik, K.; Wyganowska, M. Reasons of problems of the Polish hard coal mining in connection with restructuring changes in the period 1988-2014. Resour. Policy 2016, 48, 25-31. [CrossRef] 
53. Connor, L.H. Energy futures, state planning policies and coal mine contests in rural New South Wales. Energy Policy 2016, 99, 233-241. [CrossRef]

54. Diana, C.; Sorin, M.; Mirela, I.; Laura, M.; Sabina, I. Creating Competitive Advantage in Coal Mining Industry in Romania: A New Challenge. Procedia Econ. Financ. 2015, 23, 428-433. [CrossRef]

55. Malarz, K.; Kowalska-Styczeń, A.; Kułakowski, K. The working group performance modeled by a bi-layer cellular automaton. Simul.-Trans. Soc. Model. Simul. Int. 2016, 92, 179-193. [CrossRef]

56. Betz, M.R.; Partridge, M.D.; Farren, M.; Lobao, L. Coal mining, economic development, and the natural resources curse. Energy Econ. 2015, 50, 105-116. [CrossRef]

57. Sierpińska, M.; Bak, P. Characteristic of the capital gaining sources and financing the activity of coal mine enterprises. Part 1: Sources of the own capital. Miner. Resour. Manag. 2007, 23, 93-108.

58. Sierpińska, M.; Bąk, P. The role of corporate bonds in financing mining sector companies during an economic downturn. Miner. Resour. Manag. 2013, 29, 141-155. [CrossRef]

59. Rybak, A.; Rybak, A. Possible strategies for hard coal mining in Poland as a result of production function analysis. Resour. Policy 2016, 50, 27-33. [CrossRef]

60. Sobczyk, E.J.; Kicki, J.; Sobczyk, W.; Szuwarzyński, M. Support of mining investment choice decisions with the use of multi-criteria method. Resour. Policy 2017, 51, 94-99. [CrossRef]

61. Yu, S.; Gao, S.; Sun, H. A dynamic programming model for environmental investment decision-making in coal mining. Appl. Energy 2016, 166, 273-281. [CrossRef]

62. Wodarski, K.; Bijańska, J. Risk management in the planning of development projects in the industrial enterprises. Metalurgija 2014, 3, 276-278.

63. Turek, M. Postęp dobowy ścian ważnym składnikiem procesu restrukturyzacji technicznej. Prz. Górniczy 2008, 64, 3-9.

64. Turek, M.; Skrzyński, K.; Smoliński, A. Wpływ wybranych parametrów technicznych i organizacyjnych kopalń węgla kamiennego na wielkość jednostkowego kosztu wydobycia. Prace Naukowe GIG. Górnictwo i Środowisko 2007, I, 207-220.

65. Turek, M.; Skrzyński, K.; Smoliński, A. The relation between the technical and organizational parameters of collieries: Data set analysis. Glückauf 2009, 10, 516-521.

66. Sojda, A.; Jakowska-Suwalska, K. Wielokryterialna metoda oceny przedsiębiorstwa górniczego. Zesz. Naukowe Politech. Ślaskiej Ser. Organ. Zarz. 2014, 74, 147-157.

67. Gawlik, L. Budowa i weryfikacja modelu ekonometrycznego dla określenia liniowej zależności pomiędzy kosztami wydobycia a wielkością wydobycia. Miner. Resour. Manag. 2008, 24, 27-44.

68. Gawlik, L.; Kasztelewicz, Z. Zależność kosztów produkcji węgla w kopalni węgla brunatnego Konin" od poziomu jego sprzedaży. Prace Naukowe Inst. Górnictwa Politech. Wroc. 2015, 112, 231-242.

69. Gawlik, L. Koszty stałe i zmienne pozyskania wegla kamiennego jako element zarządzania produkcją. Polityka Energ. 2007, 10, 471-482.

70. Gawlik, L. Koszty zmienne w kosztach wytwarzania węgla w kopalniach węla kamiennego. Polityka Energ. 2010, 13, 131-144.

71. Jurdziak, L. Cena węgla brunatnego jako wyznacznik podziału zysku w układach kopalń i elektrowni część III-Obliczenia cen i zysków dla hipotetycznych danych. Prace Nauk. Inst. Górnictwa Politech. Wroc. 2007, $118,69-80$.

72. Lisowski, A. Podstawy Ekonomicznej Efektywności Podziemnej Eksploatacji Złóż; Wydawnictwo GiG, Wydawnictwo PWN: Katowice, Poland; Warszawa, Poland, 2001.

73. Magda, R. Możliwości obniżania cen zbytu węgla w zależności od przyjętego poziomu średniej akumulacji jednostkowej ze sprzedaży. Wiad. Górnicze 2014, 65, 47-52.

74. Magda, R. Ocena wpływu ograniczenia stopnia wykorzystania zdolności produkcyjnej w ścianach wydobywczych na jednostkowy koszt własny. Prz. Górniczy 2013, 9, 110-113.

(C) 2017 by the authors. Licensee MDPI, Basel, Switzerland. This article is an open access article distributed under the terms and conditions of the Creative Commons Attribution (CC BY) license (http:/ / creativecommons.org/licenses/by/4.0/). 